\title{
A small state in world politics: Iceland's search for shelter
}

\author{
Baldur Thorhallsson, Professor in political science, University of Iceland
}

\begin{abstract}
The aim of this paper is to determine Iceland's foreign policy options in relation to shelter theory. Iceland has been seeking political and economic shelter ever since the United States deserted it in 2006, by closing its military base, and in 2008, by refusing to provide it with assistance following its economic collapse. Iceland has made several new security and defence arrangements with its neighbouring states, applied for membership of the European Union and was the first European country to make a free-trade agreement with China. Moreover, the president of Iceland pressed for closer political and economic ties with Russia. Prominent Icelandic politicians frequently claim that Brexit will create a number of opportunities for Iceland and lead to closer cooperation with Britain. However, Iceland has not yet secured shelter of an extent comparable to what it had enjoyed from the United States. In this paper, we will answer questions such as: What does shelter theory tell us about Iceland's overseas relations with the US, NATO, the EU, Britain, Russia, China, and the Nordic states? Will Iceland receive more reliable shelter provided by multilateral organizations than by a single shelter provider?
\end{abstract}

Keywords: Foreign policy; small states; shelter theory; Iceland.

\section{Introduction}

Iceland has been searching for shelter ever since the US closed its military base in the country in 2006 and refused to provide it with a rescue package following the 2008 economic crash. As the American military presence had been a central component of

Icelandic Review of Politics and Administration. Vol. 14, Issue 1. Special issue on power and democracy in Iceland (61-82) (C) 2018 Contact: Baldur pórhallsson, baldurt@hi.is

Article first published online May $31^{\text {st }} 2018$ on http://www.irpa.is

Publisher: Institute of Public Administration and Politics, Gimli, Sæmundargötu 1, 101 Reykjavík, Iceland

Stjórnmál \& stjórnsýsla. 1. tbl. 14. árg. 2018. Sérhefti um vald og lýđræđi á Íslandi (61-82) Fræđigreinar

(C) 2018 Tengiliður: Baldur pórhallsson, baldurt@hi.is

Vefbirting 31. maí 2018 - Birtist á vefnum http://www.irpa.is

Útgefandi: Stofnun stjórnsýslufræđa og stjórnmála, Gimli, Sæmundargötu 1, 101 Reykjavík

DOI: https://doi.org/10.13177/irpa.a.2018.14.1.3

This work is licensed under a Creative Commons Attribution 3.0 License. 
Iceland's political shelter, it vehemently opposed the United States' intended closure of the base, never backing down from the steadfast position that a US military presence was needed in the country. Until 2006, the US was also deeply involved in the provision of economic shelter to Iceland, as it continued to pay for Iceland's defence, and had also built and run the international airport at Keflavík, the air surveillance system, and other infrastructure. Moreover, until the late 1960s, the US provided Iceland with direct economic assistance - especially in times of economic downturn. Iceland therefore turned to the US for financial assistance when the country was hit by the 2008 international financial crisis, which had caused an almost complete collapse of its financial system. The Icelandic Central Bank approached the US Federal Reserve and requested a currency swap agreement, similar to that which the Federal Reserve had offered Switzerland, the other Nordic countries, and many other countries around the globe. However, in this instance, the United States rejected Iceland's request for financial support.

To compensate for diminishing American political and economic shelter, Iceland has sought shelter from alternative sources. The aim of this paper is to examine what shelter theory can tell us about Iceland's foreign policy and its relations with the US, NATO, the EU, Britain, the Nordic states, Russia and China. Can they provide Iceland with economic and political shelter?

According to the shelter theory, small states' vulnerabilities can be categorized as being of three types: political, economic and societal. Accordingly, small states are dependent on the economic, political, and societal shelter provided by larger states and/ or regional and international organizations. The importance of shelter is related to three interrelated features: reduction of risk in the face of a possible crisis event, help in absorbing shocks during a crisis situation and assistance in dealing with the aftermath of the crisis (Thorhallsson 2010, 2011). Shelter theory draws on the International Relations literature and Small State Studies and their common claim that, in international relations, small states are in a need of an alliance or a protecting power in order to survive and prosper (Keohane 1969; Archer \& Nugent 2001). However, the shelter theory claims that small states do not solely seek security protection to safeguard their autonomy, as realists argue (Waltz 1979); they also seek to alleviate the structural weaknesses that accompany smallness, such as a small domestic market and a small public administration (Thorhallsson 2010, 2011). This paper will focus on the political and economic components of the shelter theory and leave aside the societal aspects in order to provide a more thorough analysis of Iceland's search for political and economic shelter.

The Icelandic government has been searching for shelter and has made civil security agreements - mainly concerning its waters - with the United Kingdom, Denmark, Norway, and Canada since the closure of the US military base. Airspace surveillance arrangements made with various NATO member states, including France, Germany, and the UK, and the non-NATO Nordic states Sweden and Finland, allow for the temporary presence of their jet fighters in the country. Alongside its pursuit of new bilateral agreements, Iceland has sought to strengthen its ties with NATO in an effort to shore up the organisation's provision of shelter to the country. 


\section{STJÓRNSÝSLA}

Iceland also began to consider new avenues for economic shelter. In 2009, it applied for membership of the European Union just nine months after its economic collapse and engaged in accession negotiations until 2013. After a speedy economic recovery, considerable domestic opposition to membership and a change of government, the application was put on hold. At present, at the request of the Icelandic government from 2015, Iceland is not regard as a candidate country to join the EU, though it has not withdrawn its membership application.

Icelandic politicians have also looked to non-traditional sources for support - namely China and Russia. Iceland was the first European country to sign a free trade agreement with China, which entered into force in 2014, and it cooperates with China on a number of issues. Furthermore, the former president of Iceland (1996-2016), Ólafur Ragnar Grímsson, enthusiastically campaigned for closer political and economic ties with Russia. Also, at the height of the 2008 economic crisis, Icelandic policy-makers were willing to entertain the possibility of a Russian rescue package. Moreover, in the autumn of 2015, Iceland stopped taking part in the EU's foreign policy declarations concerning the US/EU-led sanctions on Russia in order to develop closer relations with Russia, even though it still implements the sanctions. However, Icelandic-Chinese relations have not taken off in term of providing shelter for Iceland and Icelandic-Russian relations are constrained by the tension between Russia and Iceland's allies in NATO and the EU/EEA.

Furthermore, Iceland's efforts to seek economic and political shelter provided by the Nordic states intensified with the US withdrawal and has been extended to security and defence. On the other hand, the Nordic states are too weak to be able to provide Iceland with political and economic shelter in times of crisis, both in terms of resources and their reliance on their larger European neighbouring states.

Thus, Iceland has not yet secured the same degree of shelter as it used to receive from the USA. Most recently, prominent Icelandic politicians have been looking at how a post-Brexit environment may benefit the country. The minister for foreign affairs plans to establish closer political and economic ties with the United Kingdom. For instance, his master plan is to follow its lead and engage in free trade worldwide, thus strengthening Iceland's economy. Also, Iceland's security and defence could benefit from a greater UK presence in the North Atlantic and its emphasis on a stronger NATO. Accordingly, Iceland is still searching for shelter a decade after the US ceased to provide it.

The paper is divided into eight sections, including an introduction and a conclusion. The second section places Iceland in the literature of small state studies and presents the shelter theory. The third section examines Icelandic-US relations, Iceland's membership of NATO and the country's new security and defence arrangements. The fourth section analyses Iceland's search for shelter within the European project. The fifth section focuses on Iceland's relations with the Nordic states and Nordic cooperation. The sixth section examines Iceland's relations with Russia and China. The penultimate section analyses Iceland's quest for closer relations with the United Kingdom in the post-Brexit era. 


\section{Small states in the international system: The shelter theory}

Small states have inbuilt structural vulnerability related to their smallness; this manifests itself in, for example, a small domestic market, limited defence capacity and a small foreign service (Archer \& Nugent 2001). Accordingly, what distinguishes small states from large states is their lack of capabilities (Keohane 1969). The more successful states have developed certain domestic features such as democratic corporatism in order to cope with their smallness (Katzenstein 1984, 1985). They have also sought external protection. Their non-alignment may, at times, keep them out of war, but it can also place them at the mercy of larger states. Basically, small states survive due to their larger neighbouring states' willingness to respect their independence. For instance, Vital (1967) argues that small states cannot withstand stress due to their more limited resources as compared with larger states. Hence, in a historical context, the Benelux states have either depended on large states for their defences or their willingness to accept their neutrality. Their prosperity is also associated with the economic success of their larger neighbours and the willingness of the latter to grant them access to their more extensive markets. Accordingly, a small state can make domestic arrangements in order to compensate for it weaknesses, but there are limits to what it can do on its own. A small state also needs an external protector, i.e. a state that will provide it with shelter.

Shelter theory distinguishes between three forms of shelter: political, economic and societal. Political shelter takes the form of direct and visible diplomatic or military backing, as well as other strategic coverage at any given time of need provided by another state or an international organization, and/or organizational rules and norms. Economic shelter can take the form of direct economic assistance, a currency union, help from an external financial authority, beneficial loans, favourable market access, a common market, etc., all of which are provided by a more powerful country or by an international organization (Thorhallsson 2010, 2011). Societal shelter corresponds with Rokkan and Urwin's (1983) historical account on the importance of cultural features in centre-periphery relations. They argue that cultural transactions, in terms of a transfer of messages, norms, lifestyles, ideologies, myths, and ritual systems, are important in constructing centre-periphery relations.

On the other hand, protection often comes at a certain cost. For instance, Vital (1967, 79) argues that 'where the quest for protection and insurance is successful a price must normally be paid in terms of sacrifice of autonomy in the control of national resources and loss of freedom of political manoeuvre and choice'. For instance, international financial institutions' aid is often given with preconditions regarding states' domestic policies, and NATO shelter may carry considerable costs related to the application of its structure (Bailes \& Thorhallsson 2013). One state's dominance over another may include severe economic, political, and societal costs, as is shown by numerous historical examples. However, most - if not all - small states have sought shelter from their larger neighbouring states and/or regional or international organizations. For instance, most small European states have opted for shelter provided by regional multilateral organizations such as NATO, the European Union, the European Free Trade Area (EFTA) and 
the European Economic Area (EEA). The four smallest states in Europe, in terms of population, (Liechtenstein, Andorra, Monaco and San Marino) are mainly provided with shelter by their larger neighbouring states. Also, Iceland chose to seek shelter from its larger neighbouring state, the United States, and continued to enjoy considerable societal shelter from its Nordic neighbours in the post-war period (Thorhallsson \& Steinsson 2017).

\section{A small state seeking shelter in the past and present security environment}

Iceland has gained substantial political shelter from the US and NATO. By joining NATO in 1949 and signing a sweeping agreement regarding defence, trade, and economic assistance with the US in 1941 and a bilateral defence agreement in 1951, Iceland firmly aligned itself with the West, protecting itself against what the Icelandic ruling class saw as external (German and Soviet) and internal (Icelandic socialist) threats. In addition to this military shelter, the US provided Iceland with extensive diplomatic backing, as it negotiated favourable trade agreements for Iceland and allowed Iceland to circumvent the rules of international organizations. The proliferation of international organizations, as well as international laws and norms, protected Iceland. With US backing, it was able to avoid many of the costs associated with compliance with international rules and norms. Iceland's strategic importance to the US gave the island sufficient leverage in order to win against a leading world power at the time, Britain, in each of the four Cod Wars (Thorhallsson \& Steinsson 2017).

The US also provided Iceland with extensive economic shelter from early 1941 to 2006. The British and American occupations in the Second World War proved to be economic blessings for Iceland, as the occupiers injected money into the economy. This positioned Iceland as one of the wealthiest nations in the world by the end of the war. Iceland was heavily dependent on US economic assistance until 1960. It received the largest Marshall aid package per capita of any recipient and what amounted to almost a second Marshall aid package from the US in the late 1950s (Ingimundarson 1996). US aid was followed by US interventions in the Organization for European Economic Cooperation (OEEC), the IMF, and the World Bank which allowed Iceland to circumvent the rules of membership and the criteria for loans (Thorhallsson \& Steinsson 2017). Moreover, the US remained deeply involved in the provision of economic shelter to Iceland, as it continued to pay for Iceland's defence, as well as building and running the international airport at Keflavík, the air surveillance system, and other infrastructure until the closure of its military base in the country in 2006.

Importantly, the bilateral defence agreement between the countries from 1951 is still in place. In service to it, the US regularly sends jet fighters for airspace surveillance within the NATO framework and takes part in military exercises in Iceland. Interestingly, in 2016, the US Department of Defense and the Icelandic Ministry for Foreign Affairs issued a reminder about their security alliance, stating: 'The DoD and MFA reaffirm their continued commitment to close cooperation on defence and security matters'; this was 
shortly after Iceland confirmed its continuing participation in the US/EU-led sanctions against Russia in response to its destabilisation of Ukraine (IMFA \& DoD 2016).

In the absence of a US military base and permanent presence of its jet fighters for airspace surveillance, Iceland began to shift towards finding shelter elsewhere. This changing focus included both bilateral and multilateral aspects. Thus, since the closure of the US military base, Iceland has made civil security arrangements, mainly concerning its waters, with Britain, Denmark, Norway and Canada. The aim of the regular meetings with these states is to exchange information, discuss common security concerns and plan various projects regarding training and military exercises (Sveinsson 2015). Also, arrangements have been made concerning airspace surveillance with various NATO member states, such as France, Germany, and Britain (Ministry for Foreign Affairs 2017) and the non-NATO Nordic states, Sweden and Finland, allowing the temporary presence of their jet fighters in the country (Viðskiptablaðið 2014).

In another substantive sense, Iceland turned to a multilateral organisation, NATO, thus demonstrating another option available to a small state according to the small state literature. Of importance is its participation in the NATO Infrastructure Fund (Sverrisdóttir 2007), as well as remaining committed to operations in Afghanistan, Sri Lanka, and elsewhere (US Embassy in Iceland 2007a). The release of the country's first-ever defence budget, and its offering to cover all substantial costs for military exercises in the region, emphasised that Iceland was increasing its own contribution in an effort to retain political shelter (US Embassy in Iceland 2007b). This notable change in emphasis can be understood as signalling a transition from a passive foreign policy to an active one, even though changes in world affairs, and the resulting direction of foreign policy, had been noted as early as 1995 (Corgan 2002, 205; Thorhallsson 2006a). Also, in the spring of 2017, Iceland hosted 'Dynamic Mongoose 2017', a large NATO-led Submarine Surveillance Exercise (NATO 2017), an indication of NATO's refocusing on the North Atlantic.

With the decline in its geopolitical importance, Iceland could no longer rely on the threat of Russia to keep the Americans close. It is important to note that, while Iceland was at no point under imminent military threat, there was a persistent drive to seek political shelter after 2006, suggesting that it was Iceland's own self-perception, rather than any external need, that compelled it to look for shelter elsewhere (see, e.g., Thorhallsson 2006b).

However, substantial costs can also be associated with political shelter. For instance, Iceland was pressed by the US to continue to participate in US/EU-led sanctions against Russia. In the summer months of 2015, the Icelandic government considered a withdrawal of its support for the sanctions due to the Russian counter-sanctions against Iceland, which involved high costs for the nation's economy. In 2014, exports of marine products to Russia accounted for around 10 per cent of all marine exports. Nevertheless, the government backtracked on its consideration to withdraw its support for the sanctions. The decisive factor was Iceland's alignment with the US and the EU. Iceland's dependency on the US and NATO for defence and on trade with the EU outweighed its more limited trade with Russia (Thorhallsson \& Gunnarsson 2017). 
Furthermore, the good relations between Iceland and the US have not prevented the latter from placing diplomatic sanctions against the former for engaging in commercial whaling. These diplomatic sanctions, which were first set in place in 2004, have had several implications for the bilateral relations between the countries. Official visits by US ministers and high-ranking officials are restricted and US officials commonly criticise Iceland for its whaling policy at bilateral meetings and in multilateral forums. For instance, the US did not invite Iceland to take part in the 2014 global conference 'Our Ocean', which was attended by 90 states, and no US Secretary of State has visited Iceland since 2008. Moreover, the US has considered imposing targeted trade sanctions against Iceland for its commercial whaling but has stopped short of putting this into practice. Officially, the Icelandic government maintains that the diplomatic sanctions have had very little effect on the countries' relations (Sveinsson 2016). However, a high-ranking Icelandic diplomat claims that this is not true, that the sanctions have had greater consequences than were anticipated and have seriously damaged the relationship between the two countries, stressing that they would work together much more closely if it were not for the sanctions (High-ranking Icelandic Official in the Ministry for Foreign Affairs, interview, November 2015). Nevertheless, since the closure of the military base, Iceland's greater strategic importance in the North Atlantic (as regards the opening of the Arctic Ocean) has led to increased high-level contacts between the two governments, even though the countries' relations are nowhere near as close as they used to be.

\section{Iceland's quest to shelter provided by the European project}

In the summer of 2009, nine months after the country's economic collapse, Iceland applied for EU membership. This was supposed to secure a safe haven and guarantee a quick economic recovery. The Social Democratic Alliance (SDA), which initiated the application, made the adoption of the Euro its main selling point after a dramatic decline in the value of Iceland's own currency, emphasising the benefits of cheaper goods for consumers and enterprises and access to aid from the EU structural funds for rural areas, agriculture and the tourist industry. Its coalition member in government, the Left Green Movement (LGM), reluctantly accepted the membership application, in view of its opposition to membership of the EU, in order to secure the creation of the first leftwing government in Iceland. On the other hand, all the main political parties in Iceland (including the LGM) softened their stance towards the question of membership of the $\mathrm{EU}$ in the wake of the economic crash and were willing, in one way or other, to entertain the possibility of receiving shelter from the EU. For instance, in January 2009, the Progressive Party adopted a new European policy in favour of membership of the EU and the Independence Party advocated unilateral adoption of the euro in the general election in April (see, for instance, Thorhallsson \& Rebhan 2011).

However, the EU membership application was soon side-lined by the Icesave dispute, which dominated Icelandic politics until the end of the parliamentary term in 2013 and triggered a nationalist backlash and greater Euroscepticism on the part of the public and the political elite. Also, the Eurozone crisis made the euro and the EU very 
difficult to 'sell' to the Icelandic public (Thorhallsson \& Rebhan 2011). In spring 2013, the first act of the newly formed coalition government, consisting of the centre-right Independence Party and the centre-agrarian Progressive Party, was to put the EU accession negotiations on hold.

The Independence Party, the Progressive Party and the Left Green Movement claim that full participation in the European project would have a devastating effect on the primary sectors. Also, the EU project is seen as putting constraints on Iceland's economic policy: adopting the euro would be fatal to the economy, putting constraints on businesses, restricting world trade, threatening the authority of domestic institutions, diminishing sovereignty and undermining the uniqueness of the nation and its identity (Thorhallsson \& Rebhan 2011). On the other hand, from 2013 the Left Green Movement has been in favour of holding a referendum on whether or not to continue the accession process.

Opponents of EU membership point to Iceland's economic prosperity since the mid-1990s and argue that living standards have risen enormously, this being partly or mainly because of the country's status as a non-member of the EU. They point to the fact that the government and the Central Bank have been able to form their own economic and monetary policy without EU interference and the fact that Iceland recovered relatively quickly from the 2008 economic crash and, at present, has one of the highest economic growth rates in Europe (Thorhallsson \& Rebhan 2011; IMF 2016).

Despite this hostility towards EU membership or the potential cost of membership, Icelandic governments have nonetheless been forced to accept some of the constraints associated with participation in the European project. Iceland joined EEA, EFTA and Schengen because non-membership would have threatened its key economic interests in the case of EEA and EFTA, and imposed burdens on Icelandic individuals in the case of Schengen. EEA and EFTA membership entailed access to EU markets, including those for marine and agricultural products, without adverse effects for these sectors. When indisputable economic interests clash with the sovereignty and nationalism discourse, the economic interests prevail. One could say that Iceland has been able to get away with its ambivalence through the willingness of the European Union to grant it access to the Common Market without sacrificing its protectionism in the agrarian and fisheries sectors.

In 1970, Iceland joined EFTA in order to take part in the EFTA member states' freetrade agreement with the European Economic Community (EEC), which was signed two years later. The free-trade agreement with the EEC was highly beneficial for the fishing industry and the country did not start to consider other alternatives until Spain and Portugal (important markets for Icelandic marine exports) joined the EU (for instance, see Thorhallsson 2004). Membership of EFTA was very costly for the local manufacturing industry but at the same time modernized it and prepared it for increased external competition. Accordingly, Iceland's partial engagement with Europe during this period provided important economic cover according to the shelter theory. In 1961, the Icelandic government considered applying for membership of the EEC at the time of 
the British, Danish, Norwegian and Irish EEC membership applications. However, it concluded that its economy was not ready for membership (it was underdeveloped and still characterized by high tariff and non-tariff barriers to trade) (Thorhallsson 2004).

In the mid-1990s, Iceland joined the EEA and decided to participate in the Schengen scheme to secure the continuation of the Nordic passport union. Membership of the EEA is generally regarded as highly beneficial for the country. Also, Icelanders have benefited from free movement, access to higher education within the EU and participation in the Union's research funds. Membership of Schengen has secured the continuation of easy access to the other Nordic states and, importantly, participation in police collaboration in Europe. Hence, the EEA and Schengen Agreements provide important economic and political cover (in terms of security cooperation) according to the shelter theory.

However, the Icelandic government failed to take notice of the implications of the free flow of capital and did not adopt the necessary measures (which it could have done, according to the EEA Agreement, and which Norway did) to restrict its scope and the expansion of the financial sector. These factors contributed to the 2008 economic crash. Also, importantly, the structure of these agreements, and in particular the EEA Agreement, does not grant Iceland access to the EU institutions (the Council of Ministers, the European Parliament and the European Council). The absence of Icelandic representatives within the EEA decision-making processes has created a reactive approach in implementing the EEA rules, with Icelandic authorities simply applying them, though they do not necessarily reflect conditions in Iceland. For instance, the rules might fail to reflect Iceland's small size and the limited budget it has available to defend its financial sector (Prime Minister's Office 2010). Hence, Iceland is not a member of the club, which may be very costly. For instance, before, during and after the 2008 economic crash, the Icelandic government repeatedly sought assistance from the European Central Bank and the European Union, but found their doors closed against it. Moreover, the European Union stood firmly by its member states, Britain and the Netherlands, in their dispute with Iceland over the Icesave debt. Accordingly, membership of the EEA provides neither political shelter (in terms of diplomatic and defence assistance) nor economic shelter (in terms of external assistance before, in and after an economic crisis). Also, membership of the EEA and Schengen involves adopting the protector's rules and norms (Bailes \& Thorhallsson 2013).

Thus, Iceland's engagement in the European project provides a mixed picture in terms of our shelter theory. Membership of EFTA, the EEA and the Schengen scheme are largely beneficial and provide a partial economic shelter and some political shelter (within Schengen). However, these can be highly costly if Iceland does not look out for its own interests and, for instance, the Icelandic community does not benefit from participation in the Structural Funds. Also, Iceland is not a member of the club and, thus, the EU does not provide the country with essential political and economic backing during times of need. 


\section{The partial political and economic shelter provided by the Nordic states}

The Nordic Council was formed in 1953 as a forum for Nordic parliaments and governments to cooperate on common Nordic affairs. It should be emphasised that from the outset, the Nordic Council has focused on matters of law, social issues, economics, culture, science, education and transport, while side-lining, until recently, matters of defence and foreign policy (Thorsteinsson 1992a, 425). The failure of the Nordic states to create a Nordic Common Market and a Scandinavian Defence Union relates, on the one hand, to the size of the Nordic states' markets, since the cost of creating such an agreement would have outweighed the benefits, and on the other to their limited defence capabilities as compared with their larger neighbouring states. However, Nordic cooperation has provided Iceland with partial political shelter, in terms of diplomatic backing, as well as in terms of providing security shelter after the country lost its comprehensive American political shelter, as already discussed.

According to Bailes and Ólafsson $(2014,10)$, 'the significance of changing Icelandic approaches to security since 2006 lies not least in the way they have fostered a common language and common approaches between the country and its Nordic neighbours, who remain the most congenial available partners in political and cultural terms, and who - following a declaration in April 2011 - are now committed to offer mutual aid in all non-military emergencies - according to the 'Nordic solidarity clause.' In 2009, the Nordic states established Nordic Defence Cooperation (NORDEFCO). NORDEFCO involves joint exercises and activities, and the sharing of best practices. It is in part intended to share costs across the Nordic states. NORDEFCO has reportedly been successful in undertaking joint activities (Saxi 2013). Within NORDEFCO, the Icelandic Coast Guard (ICG) cooperates with the other Nordic states on procurement, education and training, but Iceland is not involved in the military aspects of the organization (Saxi 2011, 28-29, 73).

The Icelandic Coast Guard operates the NATO Iceland Air Defence System, and in this connection it cooperates closely with NATO and its member states. The ICG's main collaborating partner is the Royal Danish Navy. This collaboration is based on bilateral agreements and has a bearing on most of the ICG activities on a daily basis. The ICG regards itself as capable of dealing with its day-to-day wide-ranging obligations but as being in need of backup from its external counterparts in major crisis situations such as major shipwrecks, oil spills and national disasters. Assistance would most likely come first and foremost from the Danish Navy, then the Norwegian Coast Guard and the other members of the Arctic Coast Guard Forum (Norway, Denmark, Sweden, Finland, Russia, Canada and the US). However, the ICG relies on information from external authorities (mainly Denmark and NATO) concerning traffic, at sea and in the air, in Iceland's area of responsibility on a daily basis (High-ranking Officials of the Icelandic Coast Guard, interviews 16 May 2017).

The solidarity clause between the Nordic states against non-traditional threats ensures Nordic cooperation in terms of dealing with cyber security threats. Nordic co- 
operation is explicitly cited as an essential element of Iceland's cyber security policy (Ministry of the Interior 2015). Iceland set up a Computer Security Incident Response Team (CERT-IS), which had previously been implemented in the other Nordic states (Ministry of Foreign Affairs 2009; Ragnarsson \& Bailes 2010, 194). Since the establishment of CERT-IS, it has cooperated extensively with similar units in the other Nordic countries in sharing information about cyber threats, defence methods and equipment (CERT-IS 2014, 13; 2015, 10-12; 2016, 3-4, 10).

Iceland has been provided with wide-ranging diplomatic support (political shelter) by the Nordic states. For example, Iceland's cooperation with the Nordic states, and also the Baltic States since the early 1990s, in the World Bank Group and the IMF has granted it a role within these institutions. Hence, Iceland has appointed representatives to serve on the governing bodies of the World Bank Group through the membership of the Nordic and the Baltic states. It has also chaired the delegations of these states to the IMF (Central Bank of Iceland 2005).

Moreover, the Nordic EU member states helped Iceland to secure membership of the Schengen scheme on better terms than they received in the negotiations leading to the signature of the EEA Agreement (Eiríksson 2004). Also, the Nordic states have provided Iceland with extensive administrative assistance within EFTA and the EEA frameworks (for example, see Benediktsson 2003; Thorhallsson 2004).

Nordic cooperation has also provided Iceland with economic shelter in connection with the common Nordic labour market and burden sharing, and, at times, regarding participation in European integration. Moreover, Iceland implemented the Scandinavian welfare model and law making, which were the founding pillars of the post-war society (for instance, see Jónsson 2001). The Nordic states cooperate extensively on social affairs, allowing Icelanders to take up employment and settle down across borders, travel without passports, and claim social security on the same basis as the nationals of the state in which they are living.

In 1982, the agreement on the Nordic labour market was extended to Iceland; this ensures that Icelanders are able to take up employment and settle in the other Nordic countries without conditions (Arter 2008, 298). This proved to be highly important for Icelanders, and more generally for the Icelandic economy, in the aftermath of the 2008 economic crash. Icelanders moved to the other Nordic states in large numbers in search of employment, thus easing the pressure on the Icelandic labour market and the state's central budget during a difficult period. After a few years during which yearly population growth stayed above 2.5 per cent, the 2008 crisis caused a 0.5 per cent population reduction in 2009 and stagnation in 2010 and 2011 (Ministry of Welfare 2012, 8). This pattern is similar to the economic contraction of the 1960s (Ministry of Welfare 2012, 20-22). Data for 1971-2011 shows that approximately three-quarters of all emigrating Icelanders departed for Sweden, Denmark or Norway (Ministry of Welfare 2012, 24), with the latter being a particularly attractive destination after the 2008 crisis (Ministry of Welfare 2012, 25).

Furthermore, Nordic cooperation has provided partial economic shelter by easing 
Iceland's economic transition and adaptation to participation in European integration. For instance, during the negotiations on Iceland's accession to EFTA, the Nordic EFTA member states met Iceland's demands, set up an industrial development fund for the island, and took measures to make it easier for Iceland to export lamb to their markets (Benediktsson 2000, 83-94; see four main targets by EFTA-committee (EFTA-nefndin) 1969).

Moreover, one could say that Norway paid the bulk of Iceland's entrance fee to the European market. The EEA and Norway Grants comprise the contributions made by the EFTA/EEA states. In the period 2009-2014, Norway provided 95.8 per cent, Iceland 3.0 per cent and Lichtenstein 1.2 per cent of the $€ 993$ million set aside for the EEA Grants. In addition, Norway alone financed special Norway Grants, which amounted to approximately $€ 804$ million in this period (EEA Grants 2017). From the beginning, Norway has provided approximately 95-97 per cent of the EEA Grants (Institute of International Affairs 2014). At present, Norway makes significant net contributions to the EU through its membership of the EEA. Iceland is actually a net beneficiary: it receives more from the EU than it pays into it, while Switzerland pays slightly more to the EU than it receives in return (Bruegel 2016). Moreover, Norway pays most of the cost associated with the running of the EEA Agreement (the EFTA secretariat in Brussels, the European Surveillance Authority, and the EFTA Court) (Institute of International Affairs 2014).

The relationship between Iceland and the other Nordic states before, at the height of, and in the aftermath of the 2008 economic crash in Iceland sufficiently demonstrates the lack of comprehensive economic shelter provided by the Nordic states. However, they were more willing than other states to provide partial economic and diplomatic shelter to Iceland.

Before the crisis hit, the Nordic states provided Iceland with partial economic shelter, which came with strict conditions. Also, importantly, they provided Iceland with loans which were part of the IMF rescue package; without these loans it would have proved even harder for Iceland to receive the IMF assistance. However, when the Icelandic government failed to implement the Nordic states' conditions and Britain and the Netherlands blocked IMF assistance to Iceland, the Nordic states participated in this blocking action. Their close economic and political ties to both Britain and the Netherlands, as well as their relations with the EU, proved to be more valuable than their relations with Iceland (Thorhallsson \& Kirby 2012). Prominent Icelandic politicians characterized the involvement of the Nordic states in different ways. The President of Iceland harshly criticized them for not coming to Iceland's defence during the Icesave dispute (Morgunblaðið 2010). This reaction bore similarities to Icelandic politicians' condemnation of Nordic cooperation during the Cod Wars when the Nordic states were deemed insufficiently supportive of the Icelandic cause (Jóhannesson 2005, 20-21, 33, 84). However, at the same time, the Icelandic Foreign Minister described Nordic participation in the IMF rescue package as essential assistance (Skarphéðinsson 2010). 


\section{Iceland's reach out to Russia and China for shelter}

Icelandic policymakers have always given priority to good relations with Russia, and trade between the two countries has been extensive at times, despite Iceland's status as a founding and fully-committed member of NATO. At present, Iceland and Russia have a good bilateral relationship even though Iceland implements the US/EU-led sanctions on Russia over the Ukraine crisis, and Russia has imposed counter-sanctions on Iceland. For instance, the countries have an agreement on cooperation on Arctic affairs (Ministry for Foreign Affairs November 2011) and work closely together in the Arctic Council. A high-ranking Russian official (interview, December 2016) claims that the Russian government very much appreciates its cooperation with Iceland in the Arctic Council.

Furthermore, during his time in office (1996-2016), Iceland's president, Ólafur Ragnar Grímsson enthusiastically campaigned for closer political and economic ties with Russia. He gave priority to maintaining close cooperation with Russia over Arctic issues, and made a special effort to retain friendly ties between the two states following Russia's breach of Ukraine's sovereignty (Thorhallsson 2017). For instance, at the Arctic Dialogue (now High North Dialogue) in Norway in 2014, Grímsson railed against a Norwegian minister for bringing up the conflict in Ukraine and criticizing Russia for its involvement. The Icelandic President claimed that it would only take us (members of the Arctic Council) less than an hour to ruin the cooperation in the Arctic Council if we were to discuss all conflicts and biggest world events within its framework. ... We have to be careful not to divide states in the Arctic into different groups' (Ólafsson 19 March 2014). Moreover, in the International Arctic Forum in Arkhangelsk, the current presidents of Iceland, Russia and Finland discussed the economic developments in the Arctic, the importance of protecting the Arctic environment and the role of the Trump administration in such matters (Arctic Portal 2017).

At the height of the 2008 economic crisis, the Icelandic Central Bank hinted that the Russian Government was willing to bail Iceland out with a substantial loan and Icelandic policy-makers were willing to entertain the possibility of a Russian rescue package. The US ambassador in Reykjavik was clearly concerned about this prospect, reporting to Washington that '...the (Icelandic) PM asked at the press conference why Iceland shouldn't call on the Russians if they could help.' (US Embassy in Reykjavik 2008). The ambassador also claimed that the embassy had encouraged the Icelandic government to look for shelter elsewhere other than from Russia: 'We doubt that it would be in the interest of the U.S. or NATO for the Icelanders to be beholden to Russia, however "friendly" the loan terms may be.' (US Embassy in Reykjavik 2008). Notably, the ambassador also encouraged Washington to consider stepping in and offering assistance: 'The possibility of a Russian loan bailout as well as concerns voiced by some American bankers raise the question of whether greater USG involvement in the crisis is merited' (US Embassy in Reykjavik 2008). The response from Washington, however, was not positive. The US offered no financial assistance, and Washington officials simply expressed relief when the Russian government hinted that it was willing to bail out Iceland after the crisis hit (US Embassy in Reykjavik May 2009). While nothing eventuated from the 
Russian loan offer, the interesting fact remains that Icelandic policy-makers were willing to entertain the possibility of a Russian rescue package.

In 2015, the Icelandic government seriously considered withdrawing its support for the US/EU-led sanctions against Russia after Russia imposed counter-sanctions against Iceland. However, it backtracked on the consideration. The decisive factor was Iceland's alignment with the US and the EU, as already stated. On the other hand, in an interesting political twist, Iceland stopped taking part in the EU's declarations on the extension and amendment of the sanctions in the autumn of 2015 (Thorhallsson \& Gunnarsson 2017).

Iceland has taken part in EU's foreign-policy declarations since joining the EEA. Its alignment with the EU's foreign policy is regulated through statements on political dialogue made by governments of the EU and EFTA countries in connection with the signature of the EEA Agreement (Althingi 1993). For instance, in 2014, Iceland aligned itself with 35 out of 36 EU foreign-policy declarations (European Council 2014-16).

Until June 2015, Iceland took part in all EU's foreign-policy declarations on the sanctions against Russia. However, in October 2015, Iceland disappeared from the list of third countries aligned with the EU's decisions to renew the existing sanctions. Iceland is nowhere to be found on the list of aligned countries from that time. Accordingly, in 2015, Iceland did not take part in two EU declarations concerning the sanctions. In 2016, Iceland did not take part in any of the six EU declarations about the sanctions. Altogether, in 2015 Iceland aligned itself with 22 out of 33 EU foreign-policy declarations. In 2016, Iceland took part in 24 out of 33 declarations (European Council 201416). The Ministry of Foreign Affairs claims that the abstention from participation in the EU's foreign policy declaration was the outcome of a closer consideration of whether or not to take part in the EU's declarations. In early 2015, the Icelandic government had announced that it no longer regarded itself as a candidate country to join the EU. On the other hand, the main reason stated for non-alignment with the declarations was one of time constraints: the EU does not give Iceland enough time to respond to invitations to align itself with it decisions (High-Ranking Official in the Icelandic Ministry for Foreign Affairs, interview, January 2017). The EU simply invites Iceland to take part in its foreign-policy declarations without prior political dialogue (High-Ranking Official in the Icelandic Ministry for Foreign Affairs, interview, December 2016). On the other hand, the decision not to take part in the declarations concerning the sanctions on Russia was a deliberate one intended to keep good relations with Russia, and an attempt to have Russia lift its counter-sanctions on Iceland even though the country still applied the US/EU-led sanctions against it. Accordingly, Iceland keeps a lower international profile about its participation in the sanctions, and the international media no longer report that Iceland has aligned itself with the EU's sanctions. Importantly, Iceland has managed to maintain good relations with Russia even though the countries have adopted sanctions against each other. According to a high-ranking Russian official, 'Iceland was not sovereign and not independent in its decision-making' when it decided to take part in the US-EU lead sanctions on Russia. 'Iceland had to play the game of the United States' (High-Ranking Russian Official, interview, November 2016). 
Iceland has significantly extended its cooperation with China. For instance, it was the first European country to sign a free-trade agreement with China, which entered into force in 2014. This covers trade in goods and services, rules of origin, trade facilitation, intellectual property rights, competition and investment. The free-trade agreement also stipulates that the two states should enhance their co-operation in a number of areas, including on labour and environmental issues (Ministry for Foreign Affairs 2013). Also, the countries cooperate on geothermal energy (Iceland abroad n.d.) and have signed a number of other cooperation agreements relating to the Arctic, such as cooperation on oil exploration in the Dreki area (National Energy Agency 2014) and a Memorandum of Understanding on Cooperation in the field of Marine and Polar Science (Government of the People's Republic of China and Government of Iceland 2013), and the Icelandic shipping company Eimskip is having two new vessels built in China, both designed for the North Atlantic (Eimskip 2017). Moreover, Iceland cooperates with China with the Nordic states under the umbrella of the Nordic Council of Ministers and other SinoNordic frameworks (Nordic Council of Ministers 2017).

Moreover, Iceland was a firm supporter of an observer status for China in the Arctic Council - the main body for Arctic Governance. Iceland has chosen an inclusive approach within the Arctic Council in order to strengthen the multilateral framework of decision-making in the Council. Hence, Iceland has welcomed observer status for a number of global actors, such as China and the EU, not only to raise their interests in Iceland but also to balance the more powerful members of the Arctic Council, namely the USA and Russia (Bailes et al. 2014, 84).

\section{A quest for shelter provided by a powerful neighbour in a post- Brexit world}

The Icelandic Minister for Foreign Affairs has seized the opportunity for Iceland to develop closer political and economic relations with the United Kingdom following its decision to leave the European Union. There have been frequent contacts at ministerial and administrative levels between the Icelandic and the British government since the Brexit referendum. Both countries seem to be eager to establish closer relations in the light of the coming post-Brexit world (see Thorhallsson \& Gunnarsson forthcoming).

Many prominent Icelandic politicians are sympathetic towards Brexiteers and frequently talk about opportunities for Iceland associated with Britain's departure from the European Union. According to the Foreign Minister, Pórðarsson, Brexit - and the associated opportunities it may provide - has become a priority issue in the Icelandic Ministry for Foreign Affairs. The minister hopes that the UK, as the fifth-largest world economy, will become the leader of free trade in the world after it leaves the EU. This in turn might allow Iceland - as the UK's neighbouring state and established trade partner - to utilize this opportunity and engage in free trade worldwide, thus strengthening its economy (Thorhallsson \& Gunnarsson forthcoming).

Importantly, the minister has taken the lead within the European Free Trade Association (EFTA) in offering to welcome the UK back into the organization. On the 
other hand, Norway and Switzerland have been sceptical about Britain's re-entry and worry that it would change the power balance within the organization and possibly lead to disputes with the EU (Thorhallsson \& Gunnarsson forthcoming).

According to the Icelandic Ministry for Foreign Affairs, Brexit will not have any effect on the security and defence relations between Iceland and the UK. However, the UK is likely to campaign for a stronger NATO in the post-Brexit era, and in the light of growing disputes between the West and Russia, might seek to strengthen its security and defence ties with Iceland - a move that would be welcomed by most of the Icelandic political elite. Iceland's security and defence would benefit from greater levels of activity by the Royal Navy (RN) and Royal Air Force (RAF) in the North Atlantic. Also, Icelandic decision-makers have pointed to the possibility of strengthening North Atlantic cooperation amongst Iceland's closest neighbouring states and entities in the post-Brexit world (Thorhallsson \& Gunnarsson forthcoming).

Associated difficulties for Iceland following Britain departure from the EEA have been set aside in the public political discourse of most Icelandic politicians. On the other hand, the Ministry for Foreign Affairs and individual foreign ministers have increasingly focused on the importance of reaching a deal with the UK in order to prevent a deterioration in the countries' relations and guarantee Iceland's interests after the departure of the UK from the EU and the EEA. At present, the countries enjoy close relations but have in the past engaged in difficult disputes over fishing rights in the North Atlantic and the Icesave dispute. Iceland also had to face tough British negotiating teams during its EFTA and EEA accession talks (Thorhallsson \& Gunnarsson forthcoming). Moreover, the UK withdrawal from the EU will complicate negotiations in the North Atlantic such as regarding fishing rights and marine environmental protection. These issues are of fundamental importance for Iceland. For instance, in the wake of the Brexit negotiations, Britain has decided to withdraw from the London Fisheries Convention of 1964 which allows countries to fish near each other's coasts (McHugh 2 July 2017). Hence, Iceland has a challenging time ahead in securing shelter from the United Kingdom in the post-Brexit era.

\section{Conclusion}

The limited defence and security capacity in Iceland, the closure of the US military base in the country in 2006 and the 2008 economic crash demonstrate that the country lacks political and economic shelter. In the years between 2006 to 2009, Iceland began seeking shelter both from its historical allies and from new potential shelter providers.

First, Iceland tried to preserve remnants of the political shelter provided by the US and to resuscitate the economic shelter provided by the US in deep economic downturns. Also, Iceland deepened its involvement in NATO and started to look closer at Nordic cooperation as a form of political and economic shelter.

Second, Iceland sought shelter through new venues of cooperation. It sought comprehensive shelter as provided by full participation in the European project and entertained the possibility of acquiring shelter from Russia and China. Also, Icelandic foreign 
ministers have been looking into the possibility of aligning Iceland with the United Kingdom in a post-Brexit world. Therefore, it is evident that Iceland has not yet secured shelter of a type comparable with what it used to receive from the US and thus it keeps searching for a shelter provider.

According to the shelter theory, small states need shelter in order to survive and prosper. The Nordic states lack the economic and political resources to provide Iceland with comprehensive shelter, but they do continue to provide it with important partial shelter. Close relations with Russia and China may involve important shelter elements in terms of economic benefits but these states' authoritarian rule does not make them appealing shelter providers to small states. They are also not ideal partners for small democratic states seeking political shelter, where governance is based on the rule of law and respect for human rights. Policy-makers in Iceland must consider carefully consider whether Russia and China are attractive allies for them, especially weighing the evidence of their lack of respect for democracy and human rights.

There are costs related to close shelter relations, such as the partial shelter that Iceland has gained through its membership of the EEA; membership of the EU would also entail costs. Moreover, the wide-ranging shelter provided by the US in the post-war years included costly elements, such as severe domestic disputes and a rift arising from the countries' relations. Furthermore, a small state in a need of shelter must be aware of the fact that the shelter provider may not be willing to help in a time of crisis and may even partially or fully withdraw its support. Accordingly, it must develop some basic domestic expertise, be prepared to seek other shelter alternatives, and be careful not to close any doors in that respect, if possible.

Importantly, the US desertion of Iceland illustrates the risk associated with a small state's dependence on shelter provided by a single shelter provider. The traditional International Relations literature underestimates the role of multilateral organizations, such as the Nordic Council and the European Union, in providing political and economic shelter to small states. Benefits of close encounters between small states and multilateral organizations may not be as noticeable as the advantages of close shelter relations with a large neighbouring state. For instance, the benefits that Iceland derived from the political and economic shelter provided by the US were more conspicuous, and received much greater attention from the public, politicians, and academics than the shelter provided as a result of Nordic cooperation and membership of NATO, EFTA, EEA, and Schengen.

Small states may receive more reliable shelter provided by a multilateral organization than provided by a single shelter provider. There is a greater risk of a single shelter provider backing out from the shelter relationship than there is of a multilateral organization doing something similar. Risk is shared and spread in multilateral fora and members often operate according to set rules based on mutual assistance to other members in times of need. Accordingly, multilateral fora bind larger states to helping out their smaller partners. Large states will have greater difficulties backing down from their commitments to multilateral organizations than to individual states as defined by bilateral relations. 
Policy-makers in Iceland need to consider whether membership of multilateral organizations provides a more stable shelter in order to reduce risk in the face of a crisis event, assistance during a crisis situation, and help in cleaning up in the wake of a crisis, according to the shelter theory. They must closely examine the extent to which multilateral shelter arrangements (such as membership of NATO, Schengen, the EEA, the EU, and the Nordic Council) may be more reliable providers of shelter in times of need, than a single protector, such as the USA or the UK.

\section{Acknowledgements}

This paper is published with the support of the Erasmus+ programme of the European Union. It is part of the Jean Monnet Networks project "Navigating the Storm: The Challenges of Small States in Europe”.

\section{References}

Althingi (1993). "Lög um Evrópska efnahagssvæðið”, available at http://www.althingi.is/lagas/ nuna/1993002.html

Archer, C., and Nugent, N. (2002). "Introduction: Small States and EU”, Current Politics and Economics of Europe 11(1), 1-10.

Arter, D. (2008). Scandinavian Politics Today (2nd ed.). New York: Oxford University Press.

Arctic Portal (2015). "South Korea and Iceland to Strengthen Cooperation in the Arctic", published on 9 November 2015, available at https://arcticportal.org/library/news/1611-south-korea-andiceland-to-strengthen-cooperation-in-the-arctic, accessed on 6 August 2017.

Arctic Portal (2017). "Presidents of Russia, Iceland and Finland Discuss Arctic Development", published on 31 March 2017, available at https://arcticportal.org/ap-library/news/1881-presidentsof-russia-iceland-and-finland-discuss-arctic-development, accessed on 7 July 2017.

Bailes, A.J.K., and Thorhallsson, B. (2013). "Instrumentalizing the European Union in Small State Strategies”, European Integration 35(2), 99-115.

Bailes, A.J.K., and Ólafsson, K.T. (2014a). "Developments in Icelandic Security Policy", Icelandic Review of Politics and Administration 10(2), 1-15.

Bailes, A.J.K., Cela, M., Kjartansdóttir, K., and Schram, K. (2014). "Iceland: Small but Central", in A. Spruds, and T. Rostoks (eds.), Perceptions and Strategies of Arcticness in Sub-Arctic Europe. Riga: Latvian Institute of International Affairs.

Benediktsson, E. (2000). Ísland og Evrópupróunin 1950-2000. Reykjavík: Fjölsýn forlag.

Benediktsson, E. (2003). Iceland and the European Development. Reykjavík: Almenna bókafélagið.

Central Bank of Iceland (2005). "Ísland og Alpjóðagjaldeyrissjóðurinn", available at http://www.sedlabanki.is/?PageID=320, accessed on 26 August 2005.

Computer Emergency Response Team-Iceland (2014). “Ársskýrsla CERT-ÍS fyrir árið 2013”, available at https://www.cert.is/files/arsskyrsla2013.pdf

Computer Emergency Response Team-Iceland (2015). “Ársskýrsla CERT-ÍS fyrir árið 2014”, available at https://www.cert.is/files/CERT-IS.arsskyrsla2014.pdf

Computer Emergency Response Team-Iceland (2016). “Ársskýrsla CERT-ÍS fyrir árið 2015”, available at https://www.cert.is/files/CERT-IS_Arsskyrsla2015.pdf

Corgan, M.T. (2002). Iceland and Its Alliances: Security for a Small State. New York: The Edwin Mellen Press.

Darvas, Z. (2016). "Single Market Access from Outside the EU: Three Key Prerequisites", Bruegel blog, published on 19 July 2016, available at http://bruegel.org/2016/07/single-market-accessfrom-outside-the-eu-three-key-prerequisites/

EEA Grants (2017). "Who We Are", available at http://eeagrants.org/Who-we-are 


\section{STJÓRNSÝSLA}

EFTA-committee (EFTA-nefndin) (8 January 1969). Unpublished Record of a Ministry of Commerce Meeting.

Eimskip (2017). "Eimskip Signs a Contract for Building of Two New Container Vessels in China", available at https://globenewswire.com/news-release/2017/01/25/910638/0/en/Eimskip-signsa-contract-for-building-of-two-new-container-vessels-in-China.html, accessed on 7 July 2017.

Eiríksson, S. (2004). "Deeply Involved in the European Project: Membership of Schengen", in B. Thorhallsson, (ed.), Iceland and European Integration: On the Edge. New York: Routledge.

European Council, Council of the European Union (2014-16). Declarations by the High Representative Press Releases and Statements. Available at http://www.consilium.europa.eu/en/ press $/$ press- $\quad$ releases $/ ? \mathrm{q}=$ ukraine $\& \mathrm{frDt}=\& \mathrm{frDt} \_$submit $=\&$ toDt $=\&$ toDt_submit $=\& \mathrm{fn} \% 5 \mathrm{~B}$ $\% 5 \mathrm{D}=555 \& \mathrm{st} \mathrm{Dt}=20170221$

Iceland Abroad (n.d.). "China and Iceland Sign Agreements on Geothermal and Geoscience Cooperation and in the Field of Polar Affairs", available at http://www.iceland.is/iceland-abroad/cn/english/news-and-events/china-and-iceland-sign-agreements-on-geothermal-and-geoscience-cooperation-and-in-the-field-of-polar-affairs/8882, accessed on 7 July 2017.

IMF (2016). "Iceland: 2016 Article IV Consultation-Press Release; Staff Report; and Statement by the Executive Director for Iceland”, 22 June 2016. Accessed 4 April 2018 at https://www.imf.org/en/ Publications/CR/Issues/2016/12/31/Iceland-2016-Article-IV-Consultation-Press-Release-StaffReport-and-Statement-by-the-43996

IMFA \& DoD (2016). "Joint Declaration Between Iceland and the United States on Security and Defense Affairs", Department of Defense of the United States of America and the Ministry of Foreign Affairs in Iceland, available at https://www.mfa.is/media/Varnarmal/Joint-Declaration-Signed-.PDF

Government of the People's Republic of China \& Government of Iceland (2013). "Joint Statement between the Government of the People's Republic of China and the Government of Iceland on Comprehensively Deepening Bilateral Cooperation”, created on 15 April 2013, available at https:// eng.forsaetisraduneyti.is/media/frettir1/Joint-statement-of-PMs-Iceland-China-2013.pdf, accessed on 5 August 2017.

High-ranking Icelandic Coast Guard Officials (2017). Interview with two High-ranking Officials from the Icelandic Coast Guard on 16 May 2017, Reykjavik.

High-ranking Icelandic Official in the Ministry for Foreign Affairs (2015). Interview with a High-ranking Icelandic Official in the Ministry of Foreign Affairs in November 2015, Reykjavik.

High-ranking Icelandic Official in the Ministry of Foreign Affairs (2016). Interview with a High-ranking Icelandic Official in the Ministry of Foreign Affairs in December 2016, Reykjavik.

High-ranking Icelandic Official in the Ministry for Foreign Affairs (2017). Interview with a High-ranking Official in the Icelandic Ministry of Foreign Affairs in January 2017, Reykjavik.

High-ranking Russian Official (2016). Interview with a High-ranking Russian Official in November 2016, Reykjavik.

Ingimundarson, V. (1996). Í eldlinu kalda strídsins: Samskipti Íslands og Bandarikjanna 1945-1960. Reykjavík: Vaka-Helgafell.

Institute of International Affairs (2014). “Aðildarviðræður Íslands við ESB”, Reykjavík: Alpjóðamálastofnun, Háskóli Íslands, available at http://ams.hi.is/wp-content/uploads/2014/03/Uttekt-AMSum-adildarvidraedur-Islands-vid-ESB.pdf

Jóhannesson, G.T. (2005). Sympathy and Self-Interest: Norway and the Anglo-Icelandic Cod Wars. Oslo: Institutt for Forsvarsstudier.

Jonsson, G. (2001). "The Icelandic Welfare State in the Twentieth Century", Scandinavian Journal of History 26(3), 249-267.

Katzenstein, P. (1984). Corporatism and Change: Austria, Switzerland, and the Politics of Industry. Ithaca; London: Cornell University Press.

Katzenstein, P. (1985). Small States in World Markets: Industrial Policy in Europe. London: Cornell University 
Press.

Keohane, R.O. (1969). “Lilliputians’ Dilemmas: Small States in International Politics”, International Organization 23(2), 291-310.

McHugh, M. (2017). "UK's Withdrawal from Fishing Deal is 'Unwelcome and Unhelpful,- says Government", The Independent, published on 2 July, available at http://www.independent.ie/ irish-news/politics/uks-withdrawal-from-fishing-deal-is-unwelcome-and-unhelpful-says-government-35886609.html, accessed on 2 July 2017.

Ministry for Foreign Affairs (2011). "Iceland and Russia: Communication Cable, Adoption, the Arctic and Geothermal Energy", available at https://www.mfa.is/news-and-publications/nr/6512

Ministry for Foreign Affairs (2009). “Áhættumatsskýrsla fyrir Ísland (Threat Assessment for Iceland)", available at https://www.stjornarradid.is/media/utanrikisraduneyti-media/media/skyrslur/ skyrsla_um_ahattumat_fyrir_island_a.pdf, accessed on 3 June 2017.

Ministry for Foreign Affairs (2013). "Free Trade Agreement between Iceland and China", available at https://www.mfa.is/foreign-policy/trade/free-trade-agreement-between-iceland-and-china/

Ministry for Foreign Affairs (2017). “Öryggis- og varnarmál: Samningar við grannríki”, Ministry of Foreign Affairs, available at https://www.stjornarradid.is/verkefni/utanrikismal/oryggis-og-varnarmal/, accessed 9 May 2017.

Ministry of the Interior (2015). "Icelandic National Cyber Security Strategy 2015-2026: Plan of Action 2015-2018”, published in April 2015, available at https://eng.innanrikisraduneyti.is/media/ frettir-2015/Icelandic_National_Cyber_Security_Summary_loka.pdf

Ministry of Welfare (2012). "Fólksflutningar til og frá Íslandi 1961-2011 með áherslu á flutninga á samdráttarskeiðum”, published in March 2012, Reykjavik: Ministry of Welfare, available at https:/ / www.velferdarraduneyti.is/media/rit-og-skyrslur2012/Folksflutningar_03042012.pdf

Morgunblaðið (2010). "Forsetinn gagnrýnir norðurlönd", 8 March.

NATO (2017). "NATO Submarine Warfare Exercise Begins in Iceland", published on 27 June 2017, available at http://www.shape.nato.int/news-archive/2017/nato-submarine-warfare-exercise-begins-in-iceland

National Energy Authority (2014). "Orkustofnun Grants a Third Licence in the Dreki Area", published on 22 January 2014, available at http://www.nea.is/the-national-energy-authority/news/nr/1540, accessed on 7 July 2017.

Nordic Council of Ministers (2017). "Joint Press Release: Strengthening Sino-Nordic Cooperation”, available at http://www.norden.org/is/norraena-radherranefndin/althjodasamstarf/althjodlegtsamstarf-skjoel/strengthening-sino-nordic-cooperation, accessed on 7 July 2017.

Ólafsson, S.K. (2014). "Forsetinn setti ofan í við norskan ráðherra”, Vísir, published on 19 March 2014, available at http://www.visir.is/g/2014140318637/forsetinn-setti-ofan-i-vid-adstodarutanrikisradherra-noregs, accessed on 6 July 2017.

Prime Minister’s Office (2010). "Viðbrögð stjórnsýslunnar við skýrslu rannsóknarnefndar Alpingis: Skýrsla starfshóps forsætisrætisráouneytisins", available at http://www.forsaetisraduneyti.is/media/ Skyrslur/Skyrsla-starfshops-6-mai2010.pdf, accsesed on 29 July 2011.

Ragnarsson, J.K., and Bailes, A.J.K. (2010). "Iceland and Cyber-threats", in S.B. Ómarsdóttir (ed.), bjóðarspegillinn. Reykjavík: Félagsvísindastofnun Háskóla Íslands.

Rokkan, S., and Unwin, D.W. (1983). Economy, Territory, Identity: Politics of West European Peripheries. London: Sage Publications.

Saxi, H.L. (2011). Nordic Defence Cooperation after the Cold War, Oslo Files on Defence and Security (1). Oslo: Norwegian Institute for Defence Studies.

Saxi, H.L. (2013). "Nordic Defence Cooperation (Nordefco): Balancing Efficiency and Sovereignty, NATO and Nonalignment", in K. Lepojärvi (ed.), Perspectives on European Security: State Yearbook. 2013 (pp. 68-72). Helsinki: The Finnish Committee for European Security.

Skarphédinsson, Ö. (2010). “Svar utanríkisráðherra, 138. löggjafarping — 91. Fundur”, Fundur utanrík- 


\section{STJÓRNSÝSLA}

isráðherra Norðurlanda, published on 15. March 2010, available at http://www.althingi.is/altext/ raeda/138/rad20100315T150542.html

Steinsson, S. (2016). “The Cod Wars: A Re-analysis”, European Security 25(2), 256-275.

Sveinsson, G.B. (2015). "Skýrsla Gunnars Braga Sveinssonar utanríkisráðherra um utanríkis- og alpjóðamál”, Lögð fyrir Alpingi á 144. löggjafarpingi 2014-2015, available at https://www.utanrikisraduneyti.is/media/utn-pdf-skjol/1074.pdf.

Sverrisdóttir, V. (2007, January). Security and Defense. Speech given at the University of Iceland, Reykjavik, Iceland, available at http://www.mfa.is/news-and-publications/nr/3379, accessed on 15 July 2014.

Thorhallsson, B. (ed.) (2004). Iceland and European Integration: On the Edge. London; New York: Routledge.

Thorhallsson, B. (2006a). "Iceland's Involvement in Global Affairs since the Mid-1990s: What Features Determine a State's Size", Icelandic Review of Politics and Administration 2(2), 197-223.

Thorhallsson, B. (2006b). "The Size of States in the European Union: Theoretical and Conceptual Perspectives", Journal of European Integration 28(1), 7-31.

Thorhallsson, B. (2010). "The Icelandic Crash and its Consequences: A Small State without Economic and Political Shelter", in R. Steinmetz and A. Wivel (eds.), Small States in Europe: Challenges and Opportunities. Ashgate Publishing, 199, 216.

Thorhallsson, B. (2011). "Domestic Buffer versus External Shelter: Viability of Small States in the New Globalised Economy”, European Political Science, Symposium, European Consortium for Political Research 10, 324-336.

Thorhallsson, B. (2017). “A Small State Seeking Shelter: Iceland's Search for Shelter”, Policy Brief, SSANSE Project: Small States and the Changing Global Order: New Zealand Faces the Future. Christchurch: New Zealand, 3-4 June 2017.

Thorhallsson, B. and Kirby, P. (September 2012). "Financial Crisis in Iceland and Ireland: Does EU and Euro membership matter?", Journal of Common Market Studies 50(5), 801-818.

Thorhallsson, B. and Gunnarsson, P. (2017). "Iceland's Relations with its Regional Powers: Alignment with the EU-US sanctions on Russia", Norwegian Institute of International Affairs (NUPI), Working Paper 874.

Thorhallsson, B., and Gunnarsson, P. (Forthcoming). "Iceland and Brexit: Iceexit of the EU Membership Application?”, Global Affairs.

Thorhallsson, B., and Rebhan, C. (2011). "Iceland's Economic Crash and Integration Takeoff: An End to European Union Scepticism?”, Scandinavian Political Studies 31(1), 53-73.

Thorhallsson, B., and Steinsson, S. (2017). "Small State Foreign Policy", in Oxford Research Encyclopedia of Politics, available at http://politics.oxfordre.com/view/10.1093/acrefore/978019022 8637.001.0001/acrefore-9780190228637-e-484

Thorsteinsson, P.J. (1992). Utanríkispjónusta Íslands og utanríkismál: Sögulegt yfirlit. Reykjavík: Hið íslenska bókmenntafélag.

U.S. Embassy in Iceland (2007a). "Iceland: Defense Bilats with NATO Allies Reflect Maturing Icelandic Approach to Security Cooperation”, published on WikiLeaks on 5 January 2007, available at https://wikileaks.org/plusd/cables/07REYKJAVIK1_a.html

U.S. Embassy in Iceland (2007b). "Iceland Presents its Vision for Nato Air Policing", published on WikiLeaks on 16 October 2007, available at https://wikileaks.org/plusd/cables/07REYKJAVIK298_a.html

U.S. Embassy in Iceland (2008). "Icelandic Economic Crisis, Time for USG to Get Involved?”, published on WikiLeaks on 8 October 2008, available at https://wikileaks.org/plusd/cables/08REYKJAVIK225_a.html

U.S. Embassy in Reykjavik, Information, May 2009.

Viðskiptablaðið (2014). “Sex F16 potur komu í gær: Norðurlandapjóðirnar munu sjá um loftrýmisgæeslu 
hér á landi á næstunni”, 28 January, available at http://www.vb.is/frettir/sex-f16-thotur-komu-igaer/101142/?q=Landhelgisgæslan

Vital, D. (1967). The Inequality of States: A Study of the Small Power in International Relations. Oxford: Clarendon Press.

Waltz, K. (1979). Theory of International Politics. Reading, Mass: Addison-Wesley. 